\title{
Studies on the ${ }^{57} \mathrm{Co}$ vitamin $\mathrm{B}_{12}$ plasma level absorption test
}

\author{
B. K. ARMSTRONG AND H. J. WOODLIFF \\ From the Department of Haematology, Royal Perth Hospital, Perth, Western Australia
}

SYNOPSIS Results of the ${ }^{57} \mathrm{Co}$ vitamin $\mathrm{B}_{12}$ plasma level absorption test are described in 163 patients. The use of intramuscular carbachol with the test and the presence or absence of current vitamin $B_{12}$ therapy did not affect the test results. Injection of $1,000 \mu \mathrm{g}$ of unlabelled vitamin $B_{12}$ during the test augmented plasma levels in patients with normal absorption but tests without this injection gave satisfactory differentiation between the normal and malabsorption ranges. Results from patients having had a gastrectomy, ileal resection, or a past history of adult coeliac disease are also described. Amongst patients with presumed Addisonian pernicious anaemia, two with unresolved equivocal results and three with falsely normal results were found. The significance of these is discussed.

Vitamin $B_{12}$ absorption tests based on the measurements of plasma levels of labelled vitamin $B_{12}$ have been described by several groups (Booth and Mollin, 1956; Goldberg, Trivedi, and Oliner, 1957; Kristensen and Hald, 1962; Nelp, McAfee, and Wagner, 1963; Doscherholmen, 1965; McCurdy, 1965; Coupland, 1966; Workman and Rusche, 1966; Forshaw and Harwood, 1966). They have the advantage over urinary excretion methods that they are not affected by renal disease, are more convenient, and the possibility of losing the specimen is less. Faecal excretion studies are time consuming and messy, whole-body counters are not generally available, and hepatic uptake studies delay the result and are inconvenient to the patient.

We have measured plasma levels in this department for the last four years and have studied a variety of factors which might affect them (Armstrong and Woodliff, 1966; Woodliff and Armstrong, 1966; Armstrong and Woodliff, 1967; Armstrong and Woodliff, 1969). We have now studied 163 patients and review our results in this paper.

Received for publication 10 November 1969.

\section{Materials and Methods}

${ }^{57} \mathrm{Co}$ vitamin $\mathrm{B}_{12}$ absorption tests were performed as previously described. In part 1 of the test the oral test dose was $0.8 \mu \mathrm{g}$ of ${ }^{57} \mathrm{Co}$ vitamin $\mathrm{B}_{18}$, while in part $210 \mathrm{mg}$ of purified hog intrinsic factor was added to this and given to patients showing malabsorption in part 1 . In tests with carbachol $0.25 \mathrm{mg}$ was injected intramuscularly half an hour before the test dose. In tests with parenteral vitamin $B_{12} 1,000 \mu \mathrm{g}$ of hydroxocobalamin was injected intramuscularly six hours after the test dose. Plasma for radioactive counting was taken eight hours after the test dose.

The results and clinical data in 163 patients having had ${ }^{57} \mathrm{Co}$ vitamin $\mathbf{B}_{12}$ absorption tests were reviewed. It was noted whether (1) parenteral vitamin $B_{12}$ or carbachol was given; (2) the patient was receiving parenteral vitamin $B_{12}$ therapy at the time of the test; (3) the result fell within malabsorption, equivocal, or normal ranges. For tests with parenteral vitamin $B_{12}$, normal was $>0.60 \%$ of the dose per litre of plasma, equivocal was 0.45 to $0.60 \%$ of dose per litre of plasma, and malabsorption was $<0.45 \%$ of dose per litre of plasma (Woodliff and 
Armstrong, 1966). For tests without parenteral vitamin $B_{12}$, normal was $>0.45 \%$ of the dose per litre of plasma, equivocal was 0.30 to $0.45 \%$ of the dose per litre of plasma, and malabsorption was $<0.30 \%$ of the dose per litre of plasma (Armstrong and Woodliff, 1969). Finally we noted whether the clinical data were consistent with the absorption test result.

\section{Results}

The results of the absorption tests are set out in Tables I to III.

\begin{tabular}{|c|c|c|c|c|c|c|}
\hline \multirow[t]{2}{*}{ Test } & \multirow[t]{2}{*}{ Group } & \multirow[t]{2}{*}{$\begin{array}{l}\text { No. of } \\
\text { Patients }\end{array}$} & \multirow[t]{2}{*}{$\begin{array}{l}\text { No. of } \\
\text { Tests }\end{array}$} & \multicolumn{3}{|c|}{$\begin{array}{l}\text { Percentage of Dose/Litre of } \\
\text { Plasma }\end{array}$} \\
\hline & & & & Range & Mean & $\begin{array}{l}\text { Standard } \\
\text { Deviation }\end{array}$ \\
\hline \multirow[t]{2}{*}{$\begin{array}{l}\text { Intramuscular carbachol and } \\
\text { hydroxocobalamin }\end{array}$} & $\begin{array}{l}\mathbf{B}_{12} \\
\text { No }_{B_{19}}\end{array}$ & $\begin{array}{r}24 \\
7\end{array}$ & $\begin{array}{r}24 \\
7\end{array}$ & $\begin{array}{l}0.00-0.39 \\
0.04-0.37\end{array}$ & $\begin{array}{l}0 \cdot 14 \\
0 \cdot 16\end{array}$ & $\begin{array}{l}0 \cdot 10 \\
0 \cdot 11\end{array}$ \\
\hline & Total & 31 & 31 & $0.00-0.39$ & 0.14 & $0 \cdot 10$ \\
\hline \multirow[t]{2}{*}{$\begin{array}{l}\text { No carbachol but intra- } \\
\text { muscular hydroxocobalamin }\end{array}$} & $\begin{array}{l}\mathrm{B}_{12} \\
\text { No } \mathrm{B}_{12}\end{array}$ & $\begin{array}{r}36 \\
6\end{array}$ & $\begin{array}{r}37 \\
6\end{array}$ & $\begin{array}{l}0.00-0.59 \\
0.00-0: 40\end{array}$ & $\begin{array}{l}0.21 \\
0.13\end{array}$ & $\begin{array}{l}0 \cdot 16 \\
0 \cdot 16\end{array}$ \\
\hline & Total & 42 & 43 & $0.00-0.59$ & 0.20 & 0.17 \\
\hline \multirow[t]{2}{*}{$\begin{array}{l}\text { No carbachol or } \\
\text { hydroxocobalamin }\end{array}$} & $\begin{array}{l}\mathrm{B}_{12} \\
\text { No } \mathrm{B}_{12}\end{array}$ & $\begin{array}{r}23 \\
6\end{array}$ & $\begin{array}{r}24 \\
7\end{array}$ & $\begin{array}{l}0 \cdot 02-0 \cdot 35 \\
0 \cdot 02-0.34\end{array}$ & $\begin{array}{l}0 \cdot 15 \\
0 \cdot 14\end{array}$ & $\begin{array}{l}0.08 \\
0.11\end{array}$ \\
\hline & Total & 29 & 31 & $0.02-0.35$ & 0.15 & 0.09 \\
\hline
\end{tabular}

Table I Part 1: ${ }^{57}$ Co vitamin $B_{12}$ absorption test results in patients with pernicious anaemia

\begin{tabular}{|c|c|c|c|c|c|c|}
\hline \multirow[t]{2}{*}{ Test } & \multirow[t]{2}{*}{ Group } & \multirow[t]{2}{*}{$\begin{array}{l}\text { No. of } \\
\text { Patients }\end{array}$} & \multirow[t]{2}{*}{$\begin{array}{l}\text { No. of } \\
\text { Tests }\end{array}$} & \multicolumn{3}{|c|}{$\begin{array}{l}\text { Percentage of Dose/Litre of } \\
\text { Plasma }\end{array}$} \\
\hline & & & & Range & Mean & $\begin{array}{l}\text { Standard } \\
\text { Deviation }\end{array}$ \\
\hline \multirow[t]{2}{*}{$\begin{array}{l}\text { Intramuscular carbachol and } \\
\text { hydroxocobalamin }\end{array}$} & $\begin{array}{l}B_{12} \\
\text { No } B_{12}\end{array}$ & $\begin{array}{l}8 \\
6\end{array}$ & $\begin{array}{l}9 \\
6\end{array}$ & $\begin{array}{l}0 \cdot 63-1 \cdot 7 \\
0 \cdot 73-2 \cdot 3\end{array}$ & $\begin{array}{l}1 \cdot 1 \\
1 \cdot 4\end{array}$ & $\begin{array}{l}0.32 \\
0.51\end{array}$ \\
\hline & Total & 14 & 15 & $0 \cdot 63-2 \cdot 3$ & $1 \cdot 2$ & 0.43 \\
\hline \multirow[t]{2}{*}{$\begin{array}{l}\text { No carbachol but intra- } \\
\text { muscular hydroxocobalamin }\end{array}$} & $\mathrm{B}_{12}$ & 21 & 22 & $\begin{array}{l}0.63-3.9 \\
0.56-2.7\end{array}$ & $\begin{array}{l}1.4 \\
1.3\end{array}$ & $\begin{array}{l}0.71 \\
0.62\end{array}$ \\
\hline & Total & 34 & 36 & $0.56-3.9$ & $1 \cdot 4$ & 0.69 \\
\hline \multirow[t]{2}{*}{$\begin{array}{l}\text { No carbachol or } \\
\text { hydroxocobalamin }\end{array}$} & $\begin{array}{l}B_{12} \\
\text { No } B_{12}\end{array}$ & $\begin{array}{l}20 \\
10\end{array}$ & $\begin{array}{l}24 \\
11\end{array}$ & $\begin{array}{l}0 \cdot 41-1 \cdot 8 \\
0 \cdot 35-2 \cdot 9\end{array}$ & $\begin{array}{l}0.82 \\
0.83\end{array}$ & $\begin{array}{l}0.29 \\
0.71\end{array}$ \\
\hline & Total & 30 & 35 & $0 \cdot 35-2.9$ & 0.83 & 0.47 \\
\hline
\end{tabular}

Table II Part 1: ${ }^{57}$ Co vitamin $B_{12}$ absorption test results in patients with normal vitamin $B_{12}$ absorption

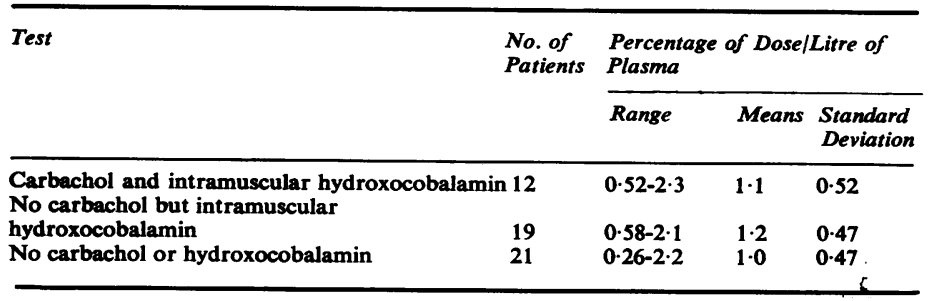

Table III Part 2: ${ }^{57}$ Co vitamin $B_{12}$ absorption test results in patients with vitamin $B_{12}$ malabsorption due to intrinsic factor deficiency
In patients with vitamin $B_{12}$ malabsorptiom $\stackrel{c}{c}$ presumed on clinical data or proven to be due to intrinsic factor deficiency (Table I), the difference between the means of tests performed wif carbachol and hydroxocobalamin intramuscir larly, with hydroxocobalamin alone, and wi neither injection are not significant. Nor were the differences significant between means of those patients receiving and those not receiving parenteral vitamin $B_{12}$ therapy at the time testing. Of the tests with intramuscular hydrox $0_{-}^{-}$ cobalamin, four results were equal to or greater than $0.45 \%(0.47 \%, 0.49 \%, 0.58 \%, 0.59 \%$ All were less than $0.45 \%$ on repeat testing. Of the tests without intramuscular hydroxocobad $\vec{\psi}$ amin, three were equal to or greater than $0.30 \%$ $(0.31 \%, 0.34 \%$, and $0.35 \%)$. All were less tha $0.30 \%$ on repeat testing.

In patients with normal vitamin $B_{12}$ absorption (Table II) the difference between means of tests performed with intramuscular hydroxocobaf amin, with and without carbachol, is not significant. However, the difference between the means of tests performed with and without intrap muscular hydroxocobalamin is highly significan $(\mathrm{p}<0.01)$. The differences are not significan between means of those receiving and not re ceiving vitamin $B_{12}$ therapy at the time of testing Of the tests with intramuscular hydroxocobab amin, one was equal to or less than $0.60 \%$ $(0.56 \%)$ but greater than $0.60 \%$ on repea testing. Of those without intramuscular hydroxom cobalamin, two were equal to or less thap $0.45 \%(0.35 \%, 0.39 \%)$; the latter was greate? than $0.45 \%$ on repeat testing whilst the formes has not been repeated.

The results of part 2 tests are given in Table II The differences between means are not significant: Adding intrinsic factor gave a rise of more thae $0 \cdot 20 \%$ on the part 1 plasma level in all cases.

Eighteen tests were done on 13 postgastrectom patients. Of 11 done with intramuscular hydroxos cobalamin the range was $0.05-0.94 \%$, five were less than $0.45 \%$, two equivocal, and four greate? than $0.60 \%$. Of the seven done without intra muscular hydroxocobalamin, the range was. $0.05-1.8 \%$; five were less than $0.30 \%$ and twa greater than $0.45 \%$.

Five patients with adult coeliac disease in remission were studied. One showed mal absorption $(0.25 \%)$, one equivocal absorption $(0.32 \%$ in a test without intramuscular hydroxo cobalamin), and three normal absorption (1.6\% $0.81 \%, 0.91 \%$ ).

Two patients known to have had ileal resectionso showed malabsorption (in part $10.04 \%, 0.18 \% \bar{P}$ uncorrected by intrinsic factor (in part $20.03 \%$, $0.11 \%)$.

Two patients had unresolved equivocal results One, D.K., previously referred to (Armstrong and Woodliff, 1966), had a serum $B_{12}$ level of less than $40 \mathrm{pg} / \mathrm{ml}$, a megaloblastic marrow, and ans abnormal Schilling test five years before testing $\frac{\hat{a}}{?}$ 
His results with intramuscular hydroxocobalamin were $0.56 \%$ and $0.57 \%$. The second patient had an absorption test result of $0.42 \%$ of the dose per litre of plasma, a serum $B_{12}$ level of 160 $\mathrm{pg} / \mathrm{ml}$ (normal range $160-875 \mathrm{pg} / \mathrm{ml}$ ), and proven gastric carcinoma.

Six tests gave normal results in three patients suspected for other reasons to have pernicious anaemia. One patient, V.P. previously referred to (Armstrong and Woodliff, 1966), had achlorhydria, gastric atrophy, and an abnormal Schilling test with three normal plasma levels in tests with intramuscular hydroxocobalamin $(0.92 \%, 2.0 \%, 1.1 \%)$. Another, F.G., had norma! ${ }^{57} \mathrm{Co}$ vitamin $\mathrm{B}_{12}$ plasma levels with and without intramuscular hydroxocobalamin $(0.96 \%, 1.34 \%)$ but a serum vitamin $B_{12}$ level of less than 40 $\mathrm{pg} / \mathrm{ml}$, a megaloblastic marrow, and an abnormal Schilling test four years before testing. The third, E.W., had a normal result with intramuscular hydroxocobalamin $(0.74 \%)$, an equivocal and then an abnormal result without intramuscular hydroxocobalamin $(0.34 \%, 0.27 \%)$, a serum vitamin $B_{12}$ level of less than $50 \mathrm{pg} / \mathrm{ml}$, positive parietal cell and intrinsic factor antibody tests, and low urinary excretion of ${ }^{57} \mathrm{Co}$ vitamin $B_{12}-6 \%$ of the dose in 48 hours (Woodliff and Armstrong, 1966).

\section{Discussion}

Our results confirm that parenteral injections of unlabelled vitamin $B_{12}$ augment plasma levels of label following an oral dose of radioactive vitamin $\mathbf{B}_{12}$. They also confirm, however, that tests performed without the augmenting dose are as satisfactory as those performed with it in separating normal patients from those with vitamin $\mathbf{B}_{\mathbf{1 2}}$ malabsorption. Equivocal results and some overlap occur with both tests but repeat testing usually gives an unequivocal result. Our experience also indicates that stimulating gastric secretion with carbachol and the presence or absence of vitamin $B_{12}$ therapy have no influence on the test results. The use of the former may, therefore, be abandoned and the latter need not be taken into consideration in interpreting results.

The occurrence of normal plasma levels of ${ }^{57} \mathrm{Co}$ vitamin $\mathrm{B}_{12}$ in patients with strong suspicion of, or demonstrated by the Schilling test, vitamin $B_{12}$ malabsorption, has been reported by other workers (McCurdy, 1965; McIntyre and Wagner, 1966). McIntyre and Wagner (1966) found a $31 \%$ incidence of false normals if the lower limit of normal was set at $0.25 \%$ of the dose per litre and $7 \%$ if the lower limit of normal was set at $0.65 \%$ of the dose per litre. On our criteria, three out of $88(3.4 \%)$ patients in our series with vitamin $B_{12}$ malabsorption gave falsely normal results. Thus we have not found this problem to be as great as@ did McIntyre and Wagner (1966), and consider that, provided the absorption test results are always interpreted in the light of other clinical and laboratory data and equivocal tests are repeated, it is unlikely to lead to misdiagnosis.

We cannot offer an explanation for the dis $=-\frac{?}{0}$ crepant results.

In its simplest form, the ${ }^{57} \mathrm{Co}$ vitamin $\mathrm{B}_{12} \frac{\overline{\bar{c}}}{\overline{5}}$ absorption test has the advantage of ease of performance and the avoidance of premature $\varrho$ therapy with vitamin $B_{12}$ and of the errors ${ }^{\infty}$ introduced by urine collection. These must be $\vec{\circ}$ balanced against the small number of tests $\overrightarrow{-}$ repeated because of equivocal results and the ${ }_{\sigma}^{\omega}$ smaller number of falsely normal results. We consider the test to be satisfactory for routine use.

We wish to thank Mr R. W. Stanford and staff of the Royal Perth Hospital, Department of Medical Physics, for counting the samples, and Sister A. $\vec{O}$ Smith and Dr D. Cull for their part in performing? the routine tests.

\section{References}

Armstrong, B. K., and Woodliff, H. J. (1966). Vitamin B $_{12} \bigcirc$ absorption studies: comparison of ${ }^{68} \mathrm{Co}$ vitamin $\mathbf{B}_{12}$ Schilling test and ${ }^{57} \mathrm{Co}$ vitamin $B_{12}$ plasma level test. $\frac{\supset}{\partial}$ Med. J. Aust., 1, 709-712.

Armstrong, B. K., and Woodliff, H. J. (1967). Vitamin B $_{12}$ absorption studies - the effect of carbachol and gastrin on $\mathbb{D}$ the ${ }^{57}$ Co-labelled vitamin $B_{12}$ plasma level absorption test in patients with pernicious anaemia. Med.J. Aust., 1, $\overrightarrow{\bar{O}}$ 819-820.

Armstrong, B. K., and Woodliff, H. J. (1969). Vitamin $B_{12}$ absorption studies; comparison of ${ }^{57} \mathrm{Co}$ vitamin $\mathrm{B}_{12}$ plasma levels with and without parenteral vitamin $B_{12}$. Med. J. Aust., 2, 692-693.

Booth, C. C., and Mollin, D. L. (1956). Plasma, tissue and urinary $\bar{C}$ radioactivity after oral administration of ${ }^{56} \mathrm{Co}$-labelled vitamin $\mathbf{B}_{12}$. Brit. J. Haemat., 2, 223-236.

Coupland, W. W. (1966). Plasma radioactivity after radioactive 3 vitamin $B_{12}$ given orally. Med. J. Aust., 1, 1020-1023.

Doscherholmen, A. (1965). Studies in the Metabolism of Vitamin $B_{12}$. University of Minnesota Press, Minneapolis.

Forshaw, J., and Harwood, L. (1966). Measurement of intestinal $O$ absorption of ${ }^{57} \mathrm{Co}$ vitamin $\mathbf{B}_{12}$ serum counting. J. clin.

Path., 19, 606-609.
Goldberg, S. R., Trivedi, B. K., and Oliner, L. (1957). Radioactive vitamin $B_{12}$ studies: experience with the urinary excretion test and the measurement of absorbed plasma $\mathrm{N}$ radioactivity. J. Lab. clin. Med., 49, 583-589.

Kristensen, H. P. Ø., and Hald, T. (1962). Measurement of $N$ plasma radioactivity following oral administration of $\mathrm{N}$ ${ }^{57}$ Co-labelled B B $_{12}$. Dan. med. Bull., 9, 167-170.

McCurdy, P. R. (1965). The detection of intestinal absorption of $\sigma$ $\mathrm{Co}^{57}$ tagged vitamin $\mathrm{B}_{12}$ by serum counting. Ann. intern. Med., 62, 97-102.

McIntyre, P. A., and Wagner, H. N. Jr. (1966). Comparison of the urinary excretion and 8 hour plasma tests for vitamin $\mathscr{C}$ $\mathrm{B}_{12}$ absorption. J. Lab. clin. Med., 68, 966-971.

Nelp, W. B., McAfee, J. G., and Wagner, H. N. Jr. (1963). Single T measurement of plasma radioactive vitamin $B_{12}$ as a test for pernicious anaemia. J. Lab. clin. Med., 61, 158-165.

Woodliff, H. J., and Armstrong, B. K. (1966). Vitamin $B_{12}$ absorption studies: comparison of ${ }^{87} \mathrm{Co}$ vitamin $\mathbf{B}_{12}, \bar{D}$ plasma levels, urinary excretion and faecal excretion. Med. J. Aust., 1, 1023-1025.

Workman, J. B., and Rusche, E. (1966). Cobalt-57 labeled vitamin $B_{12}$ plasma levels for the differential diagnosis of $\varrho$ macrocy tic anemias. J. nucl. Med., 7, 583-588. 